\title{
KEMUDAHAN APLIKASI GOOGLE FORM SELAMA PROSES PEMBELAJARAN SISWA MASA PANDEMI COVID 19
}

\author{
Conny \\ SMP Negeri 5 Tarakan \\ e-mail:123conny@gmail.com
}

\begin{abstract}
The purpose of this study was to obtain information about the used of the google form application during the pandemic at SMP Negeri 5 Tarakan. This study used a descriptive quantitative method with survey data collection techniques and documentation. Respondents in this study were 50 students randomly. The results of this study was students can take advantage of the google form application during learning during the Covid-19 pandemic, because of the ease of access which was approved by $92 \%$ of students, the ease of filling features which were approved by $86 \%$ of students, accurate presentation which was approved by $84 \%$ of students. , and its non-paper-based use which is approved by $70 \%$ of students so that this google form application can be used easily during the learning process.
\end{abstract}

Keywords: google forms; assessment; analytical descriptive

\begin{abstract}
ABSTRAK
Tujuan penelitian ini adalah untuk mendapatkan informasi tentang penggunaan aplikasi google form selama masa pandemi di SMP Negeri 5 Tarakan. Penelitian ini menggunakan metode kuantitatif deskriptif dengan teknik pengumpulan data survei dan dokumentasi. Responden dalam penelitian ini sebanyak 50 siswa secara acak. Hasil dari penelitian ini dan siswa dapat memanfaatkan aplikasi google form untuk selama pembelajaran di masa pandemic Covid-19, karena kemudahan aksesnya yang disetujui oleh $92 \%$ siswa, kemudahan fitur pengisiannya yang disetujui dengan $86 \%$ siswa, penyajiannya yang akurat yang disetujui dengan $84 \%$ siswa, dan penggunaannya yang tak berbasis kertas yang disetujui oleh $70 \%$ siswa sehingga aplikasi google form ini dapat digunakan dengan mudah selama proses pembelajaran.
\end{abstract}

Kata kunci: google form, penilaian; deskriptif analitik

PENDAHULUAN

Corona Virus Disease 2019 (COVID-19) juga mempengaruhi aspek pada bidang pendidikan, dimana Kemendikbud akhirnya menetapkan kebijakan RI Nomor 3 tahun 2020 dan Surat Mendikbud No 3692/MPK.A/HK/ 2020 tanggal 17 Maret 2020 perihal pelaksanaan kegiatan Pembelajaran Secara Daring dan Bekerja dari Rumah dalam Rangka Pencegahan Covid - 19, sehingga semua kegiatan yang dilakukan di luar rumah harus dihentikan sampai pandemi ini belum mereda. Hal ini juga termasuk berdampak pada aktivitas di bidang pendidikan di daerah Kota Tarakan.

Cara mengutip: Conny. (2021). Kemudahan Aplikasi Google Form selama Proses Pembelajaran Siswa Masa Pandemi Covid 19. Inteligensi: Jurnal Ilmu Pendidikan, 4(1), 45-50 
Kondisi ini dapat menyebabkan pembelajaran bukan lagi hanya dilakukan di dalam kelas tetapi tidak terbatas oleh suatu tempat yang dikenal dengan istilah sekolah (Oktavian \& Aldya, 2020). Ruang kelas bukan lagi satu-satunya tempat untuk belajar. Perkembangan ini tentu harus menjadi bahan evaluasi apakah pendidik bisa beradaptasi di dalamnya, mampu memanfaatkannya dalam pembelajaran, serta berperan menjadi jembatan penghubung bagi peserta didik dalam rangka mencapai pembelajaran 4.0 (Joenaidy, 2019).

Perkembangan teknologi informasi memiliki pengaruh besar terutama pada saat pendemi saat ini, dimana penggunaan teknologi tersebut dimanfaatkan secara maksimal dalam kegiatan proses belajar mengajar (Handarini, 2020). Pembelajaran secara daring merupakan salah satu program pembelajaran yang telah dilakukan oleh guru. Penelitian Sadikin dan Hamidah (2020) menyatakan bahwa pembelajaran secara daring adalah sebagai salah satu alternatif yang dapat mengatasi masalah pelaksanaan pembelajaran di masa pandemic covid - 19 .

Walaupun pembelajaran saat ini dilaksanakan secara daring tetapi tetap perlu dilakukan evaluasi. Oleh karena itu perlu dilakukan evaluasi terhadap program pembelajaran tersebut melalui penilaian pembelajaran (Pujilestari, 2020). Penilaian diperlukan untuk mereview proses pembelajaran yang telah berjalan, kendala, problema yang dihadapi, seberapa jauh pemahaman materi yang diberikan dan menyimpulkan apakah kegiatan pembelajaran yang dilakukan sukses atau gagal. Dengan penilaian dapat diketahui hasil dari pembelajaran dan kekurangan agar dapat diperbaiki (Salamah, 2018).
Penilaian di SMP Negeri 5 Tarakan selama pandemi menggunakan WhatsApp (WA). Dikarenakan keterbatasan memori handpone maka penilian tidak efektif. Contohnya beberapa jawaban yang terlewat untuk dinilai karena siswa bersamaan dalam mengirim jawaban, jawaban tidak dapat didownload, handpone hange karena overload. Google form saat ini merupakan alat formulir berfitur lengkap yang tersedia gratis yang bisa dibuat melalui akun Google (Nurmahmudah \& Nuryuniarti, 2019). Google form yang saat ini paling popular menawarkan pembuatan kuesioner online. Berdasarkan hal tersebut, peneliti ingin mendeskripsikan penggunaan aplikasi google form menilai pengetahuan siswa di masa pandemi di SMP Negeri 5 Tarakan. Sejak diberlakukannya PSBB di Kota Tarakan, maka proses pembelajaran pun dilaksanakan secara daring. Sedemikian hingga perlu di ketahui bagaimana hasil pembelajaran melalui penilaian.

\section{METODE PENELITIAN}

Penelitian ini berupa kuantitatif deskriptif analitik dengan teknik survei dan dokumentasi yang bertujuan untuk memperoleh gambaran penggunaan aplikasi google form. Aplikasi google form yang digunakan dalam penelitian ini sebagai alat menilai pengetahuan siswa pada pembelajaran online yang dilaksanakan di SMP Negeri 5 Tarakan. Terdapat 50 siswa yang memberikan tanggapan dengan rincian 14 siswa kelas VII, 20 siswa kelas VIII, dan 16 siswa kelas IX di SMP Negeri 5 Tarakan, dengan lima kategori respon siswa: (1) Sangat setuju dengan penggunaan aplikasi google form untuk menilai pengetahuan siswa; (2) Setuju dengan penggunaan aplikasi google 
form untuk menilai pengetahuan siswa; (3) Kadang-kadang setuju dengan penggunaan aplikasi google form untuk menilai pengetahuan siswa; (4) Tidak setuju dengan penggunaan aplikasi google form untuk menilai pengetahuan siswa; (5) Sangat tidak setuju dengan penggunaan aplikasi google form untuk menilai pengetahuan siswa. Analisis data penelitian dilakukan menggunakan model analisis Miles \& Huberman (2014) yang terdiri dari tiga tahapan, yaitu tahap pertama reduksi data, tehap kedua display data, serta tahap ketiga penarikan dan verifikasi kesimpulan.

\section{HASIL DAN PEMBAHASAN}

Surat Edaran Dinas Pendidikan Kota Tarakan nomor: 041/261/III/Disdikbud/ 2020 tentang kegiatan belajar mengajar dalam rangka pencegahan Corona Virus Disease 2019 (Covid-19) di Kota Tarakan mengubah aktivitas pembelajaran secara tatap muka menjadi online. Pertemuan kelas dilaksanakan secara online begitu pula penilaiannya. Hasil dari penelitian tersaji dalam tabel sebagai berikut.

\section{Tabel 1. Hasil survey penggunaan aplikasi google form untuk menilai pengetahuan} siswa selama pembelajaran di SMP Negeri 5 Tarakan

\begin{tabular}{llllccc}
\hline \multirow{2}{*}{ No } & \multirow{2}{*}{ Indikator } & \multicolumn{4}{c}{ Hasil survey (\%) } \\
\cline { 3 - 7 } & & SS & S & KK & TS & STS \\
\hline 1. & Kemampuan media untuk diakses & 42 & 50 & 8 & 0 & 0 \\
2. & Kemudahan mobilitas media & 42 & 52 & 6 & 0 & 0 \\
3. & Kemudahan penggunaan media & 40 & 46 & 14 & 0 & 0 \\
4. & Kemampuan media menyajikan hasil penelitian & 28 & 56 & 14 & 2 & 0 \\
5. & Ekonomis dalam penggunaan media & 30 & 40 & 18 & 10 & 2 \\
\hline
\end{tabular}

Keterangan:

SS : Sangat Setuju, sangat sesuai aplikasi google form digunakan untuk menilai pengetahuan siswa

B : Baik, sesuai aplikasi google form digunakan untuk menilai pengetahuan siswa

KK : Kadang-Kadang, cukup sesuai aplikasi google form digunakan untuk menilai pengetahuan siswa

TS : Tidak Setuju, tidak sesuai aplikasi google form digunakan untuk menilai pengetahuan siswa

STS : Sangat Tidak Setuju, sangat tidak sesuai aplikasi google form digunakan untuk menilai pengetahuan siswa

Berdasarkan survey yang dilakukan pada tabel 1, akan dideskripsikan sebagai berikut.
1) Form dapat diakses dengan mudah

Form dapat diakses dengan mudah, menurut hasil survey $42 \%$ menyatakan sangat setuju, 50\% setuju, $8 \%$ kadangkadang form dapat diakses dengan mudah. Hasil penelitian Batubara (2016) menyatakan bahwa siswa mudah mengakses google form sebagai salah satu alat penilaian pengetahuan siswa selama pembelajaran sebesar $86.7 \%$. Berdasarkan hal tersebut berarti penggunaan aplikasi google form dapat menjadi alternatif oleh guru untuk menilai pengetahuan siswa pada tingkat SMP. Semenjak adanya pandemik ini, pemanfaatan TIK menjadi kebutahan utama di segala sector termasuk kebutukan para siswa. Untuk itu siswa dituntut segera bisa menggunakan berbagai jenis 
smartphone/ laptop serta berbagai aplikasinya. Baik aplikasi utama dan aplikasi pendukung lainnya (Gokcearslan, et al., 2016). Form mudah diakses jika terkoneksi dengan jaringan internet, namun masih banyak keluhan dari orang tua akibat terjadinya peningkatan penggunaan biaya pulsa internet. Hal ini berdampak pada lambatnya respon/ pengiriman umpan balik dari siswa. Sehingga dalam penelitian ini subjek yang digunakan hanya 50 siswa dari 804 siswa.

2) Form dapat digunakan dalam berbagai jenis smartphone/ laptop yang terkoneksi jaringan internet

Berdasarkan hasil tabel 1, responden menyatakan dengan $42 \%$ sangat setuju, $52 \%$ setuju, $6 \%$ kadangkadang form dapat digunakan di berbagai jenis smartphone/ laptop. Kemampuan laptop dan telepon pintar (Hp android) untuk mengakses internet memungkinkan siswa untuk mengikuti pembelajaran, salah satu aplikasi yang dapat digunakan adalah aplikasi google form yang tersedia melalui akun Google (Haslaman \& Cevik, 2016). Namun penggunaan gawai sebagai penunjang proses pembelajaran masih harus dikontrol / diawasi oleh orang tua, karena memungkinkan adanya dampak negative penyalahgunaan aplikasi yang berlebihan (Lau, 2017).

3) Form mudah untuk digunakan dalam mengisi jawaban

Form mudah untuk digunakan dalam mengisi jawaban, menurut hasil survey $40 \%$ sangat setuju, $46 \%$ setuju, $16 \%$ kadang-kadang form mudah digunakan dalam mengisi jawaban. Google form merupakan aplikasi dari akun google yang bersifat umum, lengkap, dan dapat dilakukan melalui laptop, computer, dan bahkan smartphone. Berdasarkan hasil penelitian Sianipar (2019) didapatkan bahwa dengan penggunaan google form, responden atau siswa mengerti cara menggunakannya. Hal ini menadakan bahwa aplikasi google form dapat digunakan oleh berbagai kalangan usia.

4) Form dapat menyajikan hasil dari penilaian dengan akurat dan benar

Form dapat menyajikan hasil dari penilaian dengan akurat dan secara benar $28 \%$ sangat setuju, $56 \%$ setuju, $14 \%$ kadang-kadang, $2 \%$ tidak setuju form dapat menyajikan hasil dari penilaian. Hasil penelitian Santoso (2019) menyatakan bahwa aplikasi google form efektif untuk melakukan penilaian hasil belajar siswa.

5) Form sama sekali tidak memerlukan kertas

Form sama sekali tidak memerlukan kertas $30 \%$ sangat setuju, $40 \%$ setuju, $18 \%$ kadang-kadang setuju, $10 \%$ tidak setuju dan $2 \%$ sangat tidak setuju bahwa penggunaan form masih memerlukan kertas. Berdasarkan hasil penelitian Purwati \& Nugroho (2018), menyatakan bahwa penggunaan apilkasi google form efektif dan efisien dibandingkan dengan media konvensional seperti kertas. Berbeda dengan form tradisional yang menggunakan kertas, form online menawarkan berbagai cara untuk memperoleh sampel responden yang lebih luas dengan biaya yang lebih rendah, dengan pengajuan pertanyaan tak terbatas 


\section{SIMPULAN}

Berdasarkan hasil penelitian ini menunjukkan bahwa penggunaan aplikasi google form memberi kemudahan guru dan siswa dalam melakukan penilaian pengetahuan pembelajaran, dengan kemudahan aksesnya yang disetujui oleh 92\% siswa, kemudahan fitur pengisiannya yang disetujui dengan $86 \%$ siswa, penyajiannya yang akurat yang disetujui dengan $84 \%$ siswa, dan penggunaannya yang tak berbasis kertas yang disetujui oleh $70 \%$ siswa Guru dapat memanfaatkan aplikasi google form untuk menilai pengetahuan siswa dan siswa tidak mengalami kesulitan dalam menggunakan aplikasi. Guru dan siswa dapat menggunakan aplikasi selama terkoneksi dengan internet serta guru dan siswa dapat melihat langsung hasil segera setelah dikirim hasil pekerjaan form.

\section{DAFTAR PUSTAKA}

Batubara, H. H. (2016) Penggunaan Google Form sebagai alat penilaian Kinerja Dosen di Prodi PGMI UNISKA Muhammad Arsyad Al Banjari. Jurnal Pendidikan Dasar Islam, 8 (1).

Gokcearslan, S., Muncu, F. K., Haslaman, T., \& Cevik, Y. D. (2016) Modelling Smartphone addiction: The Role of Smartphone Usage, Self-regulation, General Selft-efficacy and Cyberloafing in University Students. Computers in Human Behavior. https://doi.org/10.1016/j.chb.2016.05. 091.

Handarini, O. I. (2020) Pembelajaran Daring Sebagai Upaya Study From Home (SFH) Selama Pendemi Covid 19. Journal Pendidikan Administrasi Perkantoran (JPAP). 8 (3).

Joenaidy, A. M. (2019) Konsep dan Strategi Pembelajaran di Era
Revolusi Industri 4.0. (diakses online pada 19 November 2020 pukul 07.52).

Lau, W. W. F. (2017) Effect of Social Media Usage and Social Media Multitasking on the Academic Performance of University Students. Computers in Human Behavior. https://doi.org/10.1016/j.chb.2016.1 1.043 .

Miles, Huberman, dan Saldana. (2014) Qualitative Data Analysis. Los Angeles: SAGE Publications.

Nurmahmudah, E., dan Nuryuniarti, R. (2019) Otak Atik Google-Forms untuk Pembuatan Kuesioner dan Quiz (diakses online pada 19 November 2020 pukul 20.36).

Oktavian, R., \& Aldya, R. F. (2020). Efektivitas Pembelajaran Daring Terintegrasi di Era Pendidikan 4.0. Didaktis: Jurnal Pendidikan Dan Ilmu Pengetahuan, 20(2), 129-135. https://doi.org/10.30651/didaktis.v20 i2.4763

Peraturan Menteri Pendidikan dan Kebudayaan Nomor 66 Tahun 2013 tentang Standar Penilaian Pendidikan.

Pujilestari, Y. (2020) Dampak Positif Pembelajaran Online dalam Sistem Pendidikan Indonesia Pasca Pandemi Covid - 19. Buletin Hukum dan Keadilan, 4 (1). http://journal.uinjkt.ac.id/index.php/a dalah/article/view/15394, diakses pada 19 November 2020 pukul 07.54 .

Purwati, D., dan Nugroho, A. N. P. (2018) Pengembangan Media Evaluasi Pembelajaran Sejarah Berbasis Google Formulir di SMA N 1 Prambanan. Jurnal Pendidikan dan Sejaran; 4 (1).

Sadikin, A., dan Hamidah, A. (2020) Pembelajaran Daring di Tengah Wabah Covid - 19. Jurnal Ilmiah Pendidikan Biologi. 6 (2). 
Santoso, P. B. (2019) Efektivitas Penggunaan Media Penialai Google FormI Terhadap Hasil Belajar Pelajaran TIK. Prosiding Seminar Nasional: Kebijakan dan Pengembangan Pendidikan di Era Revolusi Industri 4.0.

Sianipar, A. Z. (2019) Penggunaan Google Form sebagai Alat Peneliitian Kepuasan Pelayanan Mahasiswa. Journal of Infromation System, Applied, Management, Accounting and Research. 3 (1).

Surat Edaran Menteri Pendidikan dan Kebudayaan RI Nomor 3 tahun 2020 tentang Pecegahan Covid -19 pada Satuan Pendidikan.

Surat Mendikbud No 3692/MPK.A/HK/ 2020 tanggal 17 Maret 2020 perihal Pembelajaran Secara Daring dan
Bekerja dari Rumah dalam Rangka Pencegahan Covid - 19.

Surat Edaran Menteri Pendidikan dan Kebudayaan RI No 4 tahun 2020 tanggal 24 Maret 2020 tentang Pelaksanaan Kebijakan Pendidikan dalam Masa Darurat Penyebaran Covid - 19.

Surat Edaran Wali Kota Tarakan Nomor : 360/313/HK/2020 Tentang Pelaksanaan Sosial Berskala Besar Dalam Rangka Percepatan Penanganan Corona Virus Disease 2019 (COVID-19) Di Kota Tarakan.

Surat Edaran Dinas Pendidikan Kota Tarakan nomor: 041/261/III/Disdikbud/2020 tentang kegiatan belajar mengajar dalam rangka pencegahan Corona Virus Disease 2019 (Covid-19) di Kota Tarakan. 